\title{
A study of HIV/AIDS related knowledge and attitudes amongst the engineering college students
}

\author{
Arjit Kumar, Pankaj Bharadwaj, JP Srivastava \\ From $16^{\text {th }}$ International Symposium on HIV and Emerging Infectious Diseases \\ Marseille, France. 24-26 March 2010
}

\section{Background}

The present study designs to find out the knowledge and attitudes of the students of engineering colleges. The information obtained in this study will be used to demonstrate the need for development and integration of an HIV IEC training module.

\section{Methods}

One hundred seventy four randomly selected students studying in the various engineering colleges, studying in Uttar Pradesh were surveyed to assess their knowledge on HIV/AIDS. Pre tested, pre designed and preformed questionnaire was used to collect data.

\section{Results}

Response rate of $87 \%$ was obtained (174 out of 200 ). Overall, females showed less knowledge pertaining to issues related to human sexuality and HIV transmission, As compared to their male peers. Anal intercourse was observed as a risk for HIV transmission by $3 \%$ of females as compared to $20 \%$ of males. In general, there were considerable misconceptions regarding the spread and risk of HIV transmission among all engineering students. Attitudes of most of the students toward HIVinfected individuals could be best described as ambivalent. Interesting to note that female students showed more positive attitude towards HIV infected people than their male peers. Findings suggest the need of integrating IEC activities and $\mathrm{BCC}$ activities promotion in the community starting from the initial stages mainly concentrating on teenagers and youngsters.

\footnotetext{
* Correspondence: smitr2007@rediffmail.com

eras Lucknow Medical College And Hospital, Lucknow, India
}

\section{Discussion}

IEC materials and media have the potential to facilitate the development of positive behaviors and attitudes among engineering students as they relate to HIV. Studies over the past decade among health professionals in India identify the gaps in their knowledge concerning risks and transmission of HIV.

Published: 11 May 2010

doi:10.1186/1742-4690-7-S1-P141

Cite this article as: Kumar et al:: A study of HIV/AIDS related knowledge and attitudes amongst the engineering college students. Retrovirology 2010 7(Suppl 1):P141.
Submit your next manuscript to BioMed Central and take full advantage of:

- Convenient online submission

- Thorough peer review

- No space constraints or color figure charges

- Immediate publication on acceptance

- Inclusion in PubMled, CAS, Scopus and Google Scholar

- Research which is freely available for redistribution

Submit your manuscript at www.biomedcentral.com/submit 